\title{
Udan Potir: \\ Simbolik Ekologis Gordang Sambilan dan Lingkungan Alam
}

\author{
Ibnu Avena Matondang \\ Micro Ethnography Research \\ Karya Jaya \#Eka Jadi No. 9 Medan - 20144, Sumatera Utara \\ E-mail: ibnu.avena@gmail.com
}

\begin{abstract}
Abstrak
Discourse correlation of human life with nature (ecological) became the focus of attention at the present time, the phenomenon of reducedenergyand role imbalancebetween the supplyand use ofnaturalproduction to accompany the growing issue of human relationships with nature. Culturally, people have been living with the results provided by nature, human knowledge of nature has been summarized in the cultural record with human life from simple forms to the complexity of life today, the use of natural products in the form of the material to the term that refers to the relationship between humans and nature recorded in the cognitive culture. This study discusses about the ecological space of symbolic images that depict human relationships in a Batak-Mandailing culture with nature, the natural role that determines the attitude and behavior of people in the running life. Forms of ecological relationship between humans and nature are represented in the form of Gordang Sambilan musical repertoire.
\end{abstract}

Keywords : Gordang Sambilan, Symbolic, Ecology, Social Change, Nature, Culture, Batak-Mandailing

\section{Pendahuluan}

Ruang simbolik ekologis secara sederhana adalah ruang penggunaan kearifan budaya dalam bentuk material dasar Gordang Sambilan dan perubahan yang terjadi pada saat sekarang ini. Simbolik ekologis mencakup produksi simbol sosial dalam ruang urban (kota), ini memberi gambaran bahwa simbolik ekologis timbul karena adanya permintaan ekologis yang disesuaikan dengan ruang dan konteksnya, gambaran ini akan mengantarkan pada pemahaman mengenai imaji ruang simbolik ekologis yang terjadi pada Gordang Sambilan di Kota Medan.
Nas (1998) memberi gambaran jelas mengenai simbolik ekologis sebagai proses elaborasi antara kemampuan kultural dengan ekologi sosial, dimana situasi ekologi bergantung dengan kemampuan dan ketersediaan pada konteks kehidupan sosial masyarakat. Keadaan ini menyebabkan manusia memiliki kemampuan adaptasi yang dipraktekkan dalam usaha menyesuaikan kehidupan dengan ketersediaan alam.

Untuk menemukan pola interaksi antara sosial masyarakat dan ekologis maka penting untuk mendudukan pemahaman mengenai sosial masyarakat (etnis) dan ekologis yang terbentuk dari wilayah kekuasaan sosial masyarakat tersebut. 


\section{Metode Penelitian}

Penelitian yang dilaksanakan di Kota Medan, pemilihan lokasi didasarkan pada keberadaan kesenian Gordang Sambilan dengan lokasi yang dianggap merepresentasikan etnis Batak-Mandailing di Kota Medan, adapun lokasi tersebut meliputi : 1 . Kawasan Sei Mati, 2. Kawasan Simpang Limun, 3. Kawasan Sei Agul serta 4. Kawasan Medan Tembung, pemilihan lokasi penelitian ini dilakukan dengan didasarkan atas :

1. Kota Medan merupakan pusat pemerintahan Provinsi Sumatera Utara, sehingga Kota Medan adalah bentuk kota berklasifikasi modern yang dihuni oleh berbagai masyarakat dalam hal ini yang menjadi fokus adalah masyarakat Batak-Mandailing.

2. Adanya komunitas Batak-Mandailing dengan kelengkapan adat istiadat di Kota Medan.

3. Kawasan Medan Tembung dan Simpang Limun, merupakan daerah pusat transportasi antar daerah di Kota Medan yang didiami oleh masyarakat Batak-Mandailing.

4. Kawasan Sei Mati, secara historis kawasan ini merupakan kawasan yang didiami oleh masyarakat Batak-Mandailing pada saat Kesultanan Deli berkuasa di Medan.

5. Kawasan Sei Agul, merupakan kawasan alternatif yang didiami oleh masyarakat BatakMandailing di Kota Medan.
Beberapa hal pendukung dalam pemilihan lokasi penelitian, yaitu : sejarah lokasi, letak strategis lokasi. Adapun pemilihan lokasi penelitian ini juga memperhatikan karakteristik masyarakat BatakMandailing di Kota Medan, adapun karakteristik dalam hal ini dimaksudkan sebagai suatu penjelasan mengenai seberapa jauh masyarakat BatakMandailing di Kota Medan dalam memandang dan melakukan adat budaya mereka dalam kehidupan sehari-hari. Karakteristik masyarakat BatakMandailing dalam penelitian terbagi atas beberapa bagian, yaitu :

1. Karakteristik masyarakat Batak-Mandailing yang masih memegang adat budaya BatakMandailing dalam kehidupan mereka tanpa berusaha menggabungkannya dengan adat budaya lainnya yang terdapat di sekitar lingkungan,

2. Karakteristik masyarakat Batak-Mandailing yang memegang adat budaya Batak-Mandailing dan berproses menggabungkannya dengan budaya lainnya yang ada di sekitar tempat tinggal mereka,

3. Karakteristik masyarakat Batak-Mandailing yang tidak mengenal adat budaya Batak-Mandailing dan memegang budaya lain yang terdapat dalam lingkungan kehidupannya.

Adapun indikator yang dapat menuntun penelitian ini untuk mendapatkan gambaran umum mengenai karakteristik masyarakat Batak-Mandailing di Kota Medan, sebagai berikut : Linguistik, Sosial dan Budaya.

Indikator linguistik berkaitan dengan penggunaan bahasa daerah (bahasa Batak- 
Mandailing) dalam bentuk kehidupan sehari-hari, setidaknya penggunaan bahasa daerah dalam kehidupan dapat memberi sedikit gambaran mengenai kehidupan masyarakat Batak-Mandailing pada daerah penelitian ini, sedangkan indikator sosial adalah indikator yang berusaha untuk menangkap perilaku, cara pandang masyarakat Batak-Mandailing di Kota Medan seperti apakah mereka masih menggunakan dan melakukan adat budaya BatakMandailing di Kota Medan. Indikator ketiga adalah budaya, indikator ini berhubungan dengan indikator sebelumnya, yaitu linguistik dan sosial.

Melalui indikator yang telah ditetapkan sebelumnya dan digunakan untuk memberikan gambaran mengenai karakteristik masyarakat BatakMandailing di beberapa lokasi penelitian di Kota Medan, adapun hasil dari penggunaan indikator ini adalah :

1. Pada daerah Medan Maimun dari hasil observasi dan wawancara kepada informan didapatkan hasil bahwa kehidupan masyarakat BatakMandailing di lokasi ini memiliki karakteristik masyarakat Batak-Mandailing yang berpikiran dan bertindak sesuai dengan lingkungan sekitarnya dalam hal ini dijelaskan bahwa kehidupan masyarakat tersebut masih memegang adat budaya BatakMandailing dan berusaha untuk menerima budaya lain yang terdapat di sekitar lingkungan tempat tinggal mereka, hal ini disebabkan kehidupan pada daerah tersebut memiliki tingkat kepadatan penduduk yang tinggi dan intensitas pergaulan yang juga tinggi serta faktor heterogenitas penduduk di lokasi tersebut.

2. Pada daerah Medan Barat, karakteristik masyarakat Batak-Mandailing pada daerah ini adalah karakteristik masyarakat yang masih memegang adat budaya Batak-Mandailing dan tidak tertutup kemungkinan untuk menerima budaya dari luar budaya Batak-Mandailing, hal ini dilakukan sebagai salah satu upaya dalam strategi sosialisasi dengan masyarakat dengan budaya yang berbeda.

3. Pada daerah Medan Amplas, karakteristik masyarakat Batak-Mandailing yang menjadi bagian masyarakat daerah tersebut adalah karakteristik masyarakat yang memegang adat budaya BatakMandailing dan berusaha untuk mempertahankan adat budaya mereka dalam lingkungan kehidupannya, salah satunya terlihat pada tindakan mereka yang selalu didasarkan pada aturan adat maupun kebiasaan yang mereka ketahui dari daerah asal mereka (Tapanuli Selatan), hal ini disebabkan karena pada daerah ini masyarakat Mandailing mendominasi kehidupan pada daerah tersebut1.

4. Daerah Medan Tembung, pada tulisan ini lokasi penelitian pada daerah ini terbagi atas dua lokasi, yaitu : a. Pancing, dan b. Bandar Selamat, berdasarkan observasi dan wawancara didapatkan data bahwa karakteristik masyarakat BatakMandailing pada daerah ini termasuk pada karakteristik masyarakat yang masih memegang adat

\footnotetext{
$1 \quad$ Berdasarkan tulisan Matondang (2008) bahwa komposisi masyarakat Mandailing daerah Medan Amplas memiliki tingkat persentase 80 persen dari komposisi masyarakat Medan Amplas secara keseluruhan, data Kecamatan ini merujuk pada data penduduk Medan Amplas pada tahun 2007.
} 
budaya mereka, hal ini terlihat dari kehidupan mereka sehari-hari, adapun faktor yang menyebabkan hal ini adalah tingkat kepadatan penduduk yang rendah sehingga dapat dikatakan masyarakat Batak-Mandailing didaerah ini masih dapat melakukan dan mempergunakan adat budaya Batak-Mandailing seperti di daerah asal.

Masih terbuka kemungkinan munculnya lokasi lain dalam penelitian ini nantinya, hal ini dikarenakan adanya lokasi-lokasi lain yang dapat dianggap sebagai suatu lokasi yang mewakili keberadaan etnis Batak-Mandailing yang bertempat tinggal di Kota Medan.

\section{Jenis Penelitian}

Penelitian ini merupakan penelitian lapangan bersifat deskriptif dengan menggunakan pendekatan kualitatif, yang bermaksud menggambarkan secara terperinci Gordang Sambilan pada masyarakat BatakMandailing Kota Medan, selain melihat Gordang Sambilan sebagai suatu jenis alat musik tradisional Batak-Mandailing, juga akan melihat Gordang Sambilan sebagai suatu keseluruhan yang mencakup sistem sosial, budaya dan politik, hal ini sejalan dengan apa yang dikatakan Goodenough (1970:101) :

When I speak of describing a culture, then formulating a set of standards that will meet this critical test is what I have in mind. There are many other things, too, that we anthropologists wish to know and try to describe. We have often reffered to these other things as culture, also consequently.
Kutipan dari Goodenough tersebut memberi suatu penekanan terhadap proses menggambarkan suatu kebudayaan sebagai suatu hal yang memiliki keterkaitan dengan hal-hal lain dan menjadi suatu konsekwensi dari proses menggambarkan suatu budaya, sehingga berbicara mengenai Gordang Sambilan turut juga berbicara mengenai identitas etnik, simbolik ekologis, religi dan politik sebagai suatu bentuk penggambaran budaya.

Pendekatan penelitian yang digunakan peneliti adalah orientasi teoritik dalam bentuk kualitatif. Dalam pendekatan kualitatif, cara-cara memainkan, cara-cara pandang, ataupun ungkapan-ungkapan emosi dari masyarakat yang diteliti mengenai makna yang ada dalam ritual adat melalui media Gordang Sambilan, itu justru digunakan sebagai data dalam penelitian ini.

\section{Teknik Pengumpulan Data}

Dalam hal mendeskripsikan tentang makna Gordang Sambilan pada masyarakat BatakMandailing, maka dilakukan penelitian lapangan sebagai suatu upaya untuk memperoleh data primer. Selain itu diperlukan juga penelitian dari berbagai sumber kepustakaan sebagai upaya untuk memperoleh data sekunder. Dalam penelitian kualitatif, untuk memperoleh data primer tersebut, metode yang digunakan adalah metode etnografi.

Metode etnografi yang dipergunakan dalam penelitian ini adalah bentuk kerja lapangan dengan pendekatan observasi partisipasi sebagai jalan untuk mendapatkan data lapangan yang valid, hal ini 
diungkapkan oleh Van Maanen (1996:263-265) sebagai berikut :

When used as a method, ethnography typically refers to fieldwork (alternatively, participantobservation) conducted by a single investigator who 'lives with and lives like those who are studied, usually for a year or more.

\section{Data Primer}

Untuk mendapatkan data primer dalam penelitian ini dilakukan dengan cara penelitian lapangan, yaitu : observasi dan wawancara. Observasi dilakukan guna mengetahui situasi dalam konteks ruang dan waktu pada daerah penelitian.

Menurut penulis, data yang diperoleh dari hasil wawancara saja tidaklah cukup untuk menjelaskan fenomena yang terjadi, oleh karena itu diperlukan suatu aktivitas dengan langsung mendatangi tempat penelitian dan melakukan pengamatan. Pengamatan akan dilakukan pada setiap kegiatan atau peristiwa yang dianggap perlu atau berhubungan dengan tujuan penelitian.

Jackson (1987:63) mendefinisikan observasi atau pengamatan sebagai :

Observation is when you're outside what's going on and watching other people do it, or you're watching what other people have done.

Pendapat Jackson memberikan batas dalam kegiatan observasi sebagai suatu bentuk pengamatan dari luar terhadap yang diamati, sedangkan dalam bentuk pengamatan partisipasi, Jackson (1987:63) memberikan definisi mengenai partisipasi sebagai "participant-observation means you're somehow involved in the events going on, you're inside them."

Bentuk pengamatan langsung memberikan akses terhadap informasi penelitian melalui keterlibatan penulis dalam suatu kegiatan yang berlangsung dan hal ini menjadikan peneliti memiliki keterikatan terhadap subjek penelitian.

Observasi secara non-partisipasi dan partisipasi merupakan bentuk dari kerja lapangan untuk mendapatkan informasi yang mendukung jalannya suatu penelitian. Kutipan dari Emerson (1995:1-2) memberi penekanan terhadap kerja lapangan seorang etnografer sebagai :

Ethnographers are committed to going out and getting close to the activities and everyday experiences of other people. "Getting close" minimally requires physical and social proximity to the daily rounds of people's lives and activities; the field researcher must be able to take up positions in the midst of the key sites and scenes of other's lives in order to observe and understand them.

Observasi dalam penelitian ini adalah observasi dalam bentuk partisipasi maupun nonpartisipasi. Observasi partisipasi membantu untuk memahami lingkungan dan menilai keadaan yang terlihat ataupun keadaan yang tersirat (tidak terlihat, hanya dapat dirasakan) dengan memperhatikan kenyataan atau realitas lapangan, yang mana dalam observasi jenis ini peneliti tidak hanya sebatas melakukan pengamatan, tetapi juga ikut serta dalam kehidupan sehari-hari masyarakat dimana penelitian ini akan dilakukan untuk mendapatkan bentuk kedekatan secara fisik dan sosial antara peneliti dan masyarakat/informan. 
Observasi diharapkan dapat berjalan dengan baik oleh karena sebelumnya telah dilakukan prapenelitian dan peneliti telah membangun rapport yang baik. Walaupun demikian peneliti akan berusaha berfikir secara kritis sehingga data yang diperoleh di lapangan adalah benar dan sesuai dengan kenyataan yang ada di lapangan.

Observasi non-partisipasi merupakan cara yang dipilih ketika penulis tidak dapat terlibat langsung dalam suatu peristiwa tertentu yang berkaitan dengan Gordang Sambilan, sehingga penulis memiliki posisi diluar dari masyarakat.

Dalam hal perlengkapan pada saat melakukan kegiatan penelitian yang bersifat observasi nonpartisipasi, digunakan kamera dan video kamera untuk mempublikasikan hal-hal penting yang dianggap mendukung penelitian. Dengan adanya kamera dan video kamera dapat memudahkan peneliti untuk menggambarkan keadaan dari masyarakat tempat penelitian berlangsung.

Metode wawancara yang digunakan adalah wawancara mendalam (depth interview) kepada beberapa informan yang sesuai dengan tujuan penelitian. Informan disini adalah para pemainpemain Gordang sebagai informan utama, para tokoh-tokoh adat dan masyarakat Mandailing lainnya sebagai informan biasa. Para pemain Gordang Sambilan adalah mereka yang secara luas mengetahui seluk beluk tentang Gordang Sambilan tersebut secara menyeluruh, selain para pemain Gordang Sambilan tersebut tokoh-tokoh adat dan masyarakat Mandailing dikategorikan sebagai informan untuk memperoleh pengetahuan masyarakat luas tentang makna Gordang Sambilan. Besar kecilnya jumlah informan tergantung pada data yang diperoleh di lapangan.

Wawancara mendalam dilakukan dengan mendatangi para pemain Gordang Sambilan yang dianggap mempunyai dan memiliki pengetahuan yang luas dan lengkap tentang sejarah, asal-usul Gordang Sambilan. Hal ini perlu dilakukan karena pengetahuan akan sejarah, asal-usul Gordang Sambilan tersebut memberikan sumbangan yang berarti dalam memahami makna dan merupakan tema pokok penelitian yang akan dilakukan.

Teknik wawancara juga dilakukan dengan cara komunikasi verbal atau langsung dengan informan utama maupun informan biasa dengan berpedoman pada interview guide yang telah dipersiapkan sebelumnya untuk mendapatkan data konkrit yang lebih rinci dan mendalam. Perlengkapan yang digunakan pada saat wawancara adalah catatan tertulis untuk mencatat bagian-bagian yang penting dari hasil wawancara dan tape recoder serta video kamera yang digunakan untuk merekam proses wawancara dalam rangka antisipasi terhadap keabsahan data yang diperoleh ketika melakukan pengamatan dan wawancara.

\section{Data Sekunder}

Data sekunder adalah data yang bersifat tidak langsung, akan tetapi memiliki keterkaitan fungsi dengan salah satu aspek pendukung bagi keabsahan suatu penelitian. Data sekunder berupa sumber- 
sumber atau referensi tertulis yang berhubungan dengan permasalahan penelitian, data sekunder dalam penelitian ini adalah studi kepustakaan.

Studi kepustakaan sebagai teknik pengumpul data selanjutnya, dimaksudkan peneliti sebagai suatu sarana pendukung untuk mencari dan mengumpulkan data dari beberapa buku dan hasil penelitian para ahli lain yang berhubungan dengan masalah penelitian guna lebih menambah pengertian dan wawasan peneliti demi kesempurnaan akhir penelitian ini.

Adapun studi kepustakaan yang dipergunakan dalam penulisan ini, adalah : Rithaony Hutajulu dan Irwansyah Harahap (2004) yang memberikan pandangan mengenai kesenian Batak-Mandailing secara umum, Ernie Zulfan (1994) mengenai penggunaan Gondang Dua dalam ekspresi seni Batak-Mandailing, Ibnu Avena Matondang (2008) yang memberikan deskripsi visual atas Gordang Sambilan di Kota Medan dan Kartomi Margaret (1981) dengan tulisan mengenai Gordang Sambilan dari segi penggunaan musik dan sosial masyarakat setempat.

\section{Hasil dan Pembahasan}

Analisis data dalam penelitian merupakan suatu pandangan mengenai penulis untuk bersikap objektif terhadap data yang diperoleh dilapangan. Keseluruhan data yang diperoleh dari hasil penelitian lapangan tersebut akan diteliti kembali atau diedit ulang, pada akhirnya kegiatan ini bertujuan untuk memeriksa kembali kelengkapan data lapangan dan hasil wawancara.

Analisis data merupakan proses lanjutan dari bentuk catatan lapangan sebagaimana ditulis oleh Emerson (1995:4-5) sebagai :

Fieldnotes are accounts describing experiences and observations the researcher has made while participating in an intense and involved manner.

Kerja lapangan yang menjadi bahan dasar penulisan ini dilakukan pada lima lokasi yang berbeda dan tersebar di wilayah Kota Medan, yaitu : daerah Mariendal, Sei Mati, Sei Agul, Bandar Selamat dan Pancing.

Pemilihan lokasi tersebut dibangun atas konstruksi pemahaman dan pengamatan yang didasarkan atas komposisi masyarakat, interaksi antar masyarakat, intensitas penggunaan Gordang Sambilan serta keterbukaan wilayah dalam struktur kota.

Gambar 1. Peta Lokasi Penelitian (Sumber : Google Maps, diakses pada 24 Januari 2012, data diolah penulis)

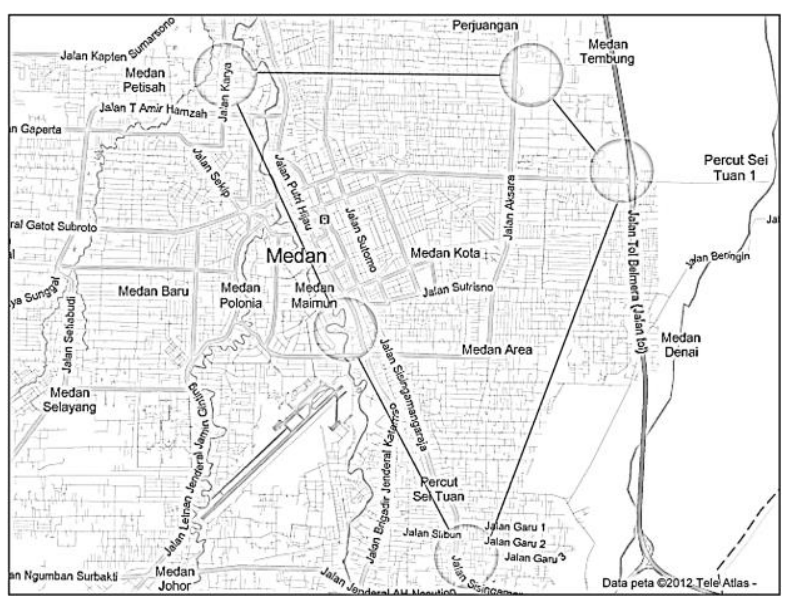


Pengumpulan data di beberapa wilayah tersebut dilakukan dengan cara wawancara, pengamatan secara aktif dan pasif, dimana aktif diartikan sebagai keikutsertaan dan berperan langsung dalam kegiatan yang dilakukan oleh masyarakat sedangkan pasif diartikan sebagai ikut serta tanpa terlibat langsung.

Proses wawancara yang dilakukan adalah bentuk wawancara bebas, dimana proses wawancara berlangsung seperti layaknya percakapan biasa sehingga dapat memberikan hasil yang baik terhadap data yang diungkapkan oleh informan. Rapport yang terjalin antara penulis dan informan memberikan dampak pada proses wawancara penelitian.

Pendokumentasian dilakukan dengan menggunakan media visual (foto,video dan audio) yang menjadi sumber nyata keberadaan peneliti dilapangan dan menjaga keabsahan data dari kerja lapangan.

\section{Batak-Mandailing}

Suku dapat dilihat sebagai suatu kesatuan komunal yang menetap pada suatu wilayah serta dibatasi oleh batas-batas geografis, pendapat ini mungkin memiliki kebenaran pada satu sisi namun pada sisi lainnya pendapat ini memiliki kekurangan dalam mendeskripsikan apa sesungguhnya suku.

Definisi tentang suku Batak (Purba, 2004:5051) adalah terdiri dari enam sub-grup, yaitu Toba, Simalungun, Karo, Pakpak, Mandailing dan
Angkola, keenam sub-group tersebut terdistribusi di sekeliling Danau Toba kecuali Mandailing dan Angkola yang hidup relatif jauh dari daerah Danau Toba, dekat ke perbatasan Sumatera Barat, di dalam kehidupan sehari-hari banyak orang mengasosiasikan kata "Batak" dengan "orang Batak Toba". Sebaliknya grup yang lain lebih memilih menggunakan nama sub-grupnya seperti Karo, Pakpak, Simalungun, Mandailing dan Angkola.

Keberadaan Batak sebagai bentuk masyarakat dengan karakteristik dinamis dan memiliki kepercayaan diri yang tinggi serta faktor perubahan yang menyebabkannya diungkapkan oleh Sibeth (1991:7) sebagai :

The Batak are very dynamic and self confidence people. Over the centuries they have able to guard their homeland against intrusion by foreigners, and it is only in the last 100 years that their way of life and culture has undergone a great change under the impact Christianity, Islam and colonialism.

Mengutip tulisan Kozok (2009:11) yang menjelaskan mengenai penggunaan istilah "Batak" yang pada saat ini sudah jarang dipergunakan sebagai istilah yang merujuk pada kelompok etnis, walaupun pada awalnya istilah "Batak" lazim dipergunakan pada masa prakolonial hingga awal penjajahan untuk merujuk pada kelompok etnis Batak itu sendiri.

Hodges (2009:75) turut memberikan definisi mengenai Batak sebagai bentuk suku (etnis) yang mendiami wilayah Sumatera Utara dan terbagi atas enam sub-grup Batak ${ }^{2}$ (Toba, Simalungun, Karo,

\footnotetext{
$2 \quad$ Hodges (2009:77) juga memberikan pandangan mengenai perubahan yang terjadi pada proses interaksi sosial,
} 
Pakpak, Mandailing, Angkola) yang berbagi persamaan dalam aspek struktur sosial, adat dan sejarah. Secara linguistik, Batak terbagi atas tiga wilayah, yaitu : a. Mandailing, Angkola dan Toba di wilayah selatan, b. Pakpak dan Karo di utara, c. Simalungun di wilayah timur laut.

Batak dalam persepsi kebudayaan dapat diterjemahkan sebagai suku yang mendiami wilayah geografis Sumatera Utara, namun pendapat lainnya mengatakan bahwa Batak tidak terbatas pada wilayah geografis Sumatera Utara saja melainkan diluar cakupan tersebut juga termasuk sebagai bagian Batak dengan syarat mutlak memiliki garis keturunan Batak (patrilineal).

Secara geografis suku Batak-Mandailing mencakup wilayah Tapanuli Selatan secara umum, wilayah Tapanuli Selatan terdiri beberapa bagian, yaitu : Kota Padang Sidempuan, Padang Lawas Utara, Padang Lawas Selatan, dan Mandailing Natal. Berdasarkan UU Nomor 12 Tahun 1998 dibentuk Kabupaten Mandailing Natal yang terpisah dari Kabupaten Tapanuli Selatan.

Deskripsi mengenai suku Batak-Mandailing penting untuk menegaskan masyarakat yang menjadi pengguna hasil ekologis.

\section{Gordang Sambilan}

Gordang Sambilan sebagai bentuk alat musik pukul (membranophone) merupakan identitas musik yang dimiliki oleh masyarakat Batak-Mandailing,

kepercayaan religi dan adat akibat kedatangan kolonial Belanda (VOC) yang merubah kondisi sosial budaya, religi dan ekonomi masyarakat Batak secara umum.
Gordang Sambilan memiliki karakteristik sebagai alat musik pukul yang berasal dari Sumatera Utara Gordang Sambilan secara harfiah berarti sembilan buah gendang, Sembilan buah gendang yang terkait dengan instrumen musik lainnya, pengertian Gordang Sambilan merupakan penjelasan yang mencakup keseluruhan ensambel Gordang Sambilan termasuk gong, simbal, dan alat musik tiup masyarakat Mandailing. Pengertian secara harfiah gondang mengandung beberapa arti: (1) alat musik; (2) nama lagu atau repertoar; (3) komposisi musik; (4) jenis musik tertentu; dan (5) sebagai musik itu sendiri.

Istilah Gordang, ada kaitanya dengan sistem bercocok tanam orang Mandailing di hauma (berladang di bukit-bukit, baik tanaman palawija maupun padi). Dalam bercocok tanam di hauma ini, ada satu alat semacam "tugal" yang disebut ordang yang digunakan untuk melubangi tanah, setelah tanah berlubang barulah biji-biji tanaman dimasukkan ke dalam tanah dan kemudian ditutup seperlunya dengan tanah. Proses kegiatan bercocok tanam ini disebut mangordang, sedangkan Siregar (1977:87) mendefinisikan Gondang merupakan gendang, dalam arti gondang tunggu-tunggu dua, Gordang adalah gendang, dalam artian sebagai gendang besar (dalam hal ini Gordang Sambilan).

\section{Simbolik Ekologis}

Kaitan antara materi pembentuk (ekologis) dan ritual (simbol) menciptakan suatu kondisi sosial yang terlegitimasi kepada penggunaan Gordang 
Sambilan yang sarat nilai-nilai ritual-magis. Gordang Sambilan memiliki hubungan ritual, dimana ideologi Gordang Sambilan didasarkan pada interaksi antara masyarakat (manusia) dengan Tuhan (Dewata ataupun penguasa alam) yang diaplikasikan pada bentuk Gordang Sambilan yang besar dari segi ukuran dan suara yang menggemuruh, kesemua hal tersebut bertujuan mendukung korelasi interaksi antara manusia dan "penguasa alam", yang digambarkan secara umum sebagai sosok yang memiliki kelebihan dari mahluk secara manusiawi.

Tabel 1

Perubahan Materi Pembentuk Gordang Sambilan

\begin{tabular}{|c|c|}
\hline $\begin{array}{c}\text { Materi Pembentuk } \\
\text { Gordang Sambilan } \\
\text { (awal) }\end{array}$ & $\begin{array}{l}\text { Materi Pembentuk } \\
\text { Gordang Sambilan } \\
\text { (perkembangan) }\end{array}$ \\
\hline $\begin{array}{c}\text { Kayu Ingul (Ruta } \\
\text { Angustifola) } \\
\text { Ritual } \\
\text { Sulit didapat } \\
\text { Harga tergantung kondisi } \\
\text { dan ketersediaan } \\
\text { Tahan lama }\end{array}$ & $\begin{array}{c}\text { Kayu Kelapa (Cocoa } \\
\text { Nucifera } L \text { ) } \\
\text { Tanpa ritual } \\
\text { Mudah didapat } \\
\text { Harga Murah } \\
\text { Tergantung penggunaan }\end{array}$ \\
\hline
\end{tabular}

Gordang Sambilan berdasarkan ekologis materi pembentuknya terbuat dari kayu ingul (Ruta Angustifola) yaitu sejenis kayu hutan dengan dinding serat yang tebal dan tidak mudah pecah serta memiliki ketahanan terhadap air. Pilihan rasional atas materi pembentuk Gordang Sambilan memberi petunjuk bahwa nenek moyang Batak-Mandailing pada masa itu telah memiliki pengetahuan yang cukup memadai atas materi pembentuk Gordang Sambilan yang kuat, tahan lama dan juga sebagai pemberian guna kembali kepada roh leluhur atas limpahan kekayaan alam.

Dahulunya materi pembentuk Gordang Sambilan dipilih dari beberapa kayu yang ditebang dan diambil dari beberapa hutan serta gunung, kearifan tradisional ini bertujuan melindungi penggunaan hutan secara berlebih sehingga dalam pengambilan pohon tersebut disertai dengan ritualritual dan pembacaan mantra tertentu yang ditujukan kepada roh nenek moyang agar mengizinkan pohon tersebut ditebang.

Kekayaan ekologis yang terdapat pada Gordang Sambilan berubah ketika Gordang Sambilan keluar dari ekologis atau wilayah asal, sehingga sulit untuk mendapatkan materi pembentuk Gordang Sambilan, selain karena perubahan wilayah dan juga karena berkurangnya pohon kayu ingul yang dapat ditebang akibat dari penebangan liar yang terjadi. Dalam konteks Kota Medan, simbolik ekologis yang terdapat pada Gordang Sambilan bergeser pada penggunaan kayu kelapa (Cocoa Nucifera L) yang memiliki usia menengah (dalam artian kayu sudah mencapai usia yang layak potong dan tidak terlalu tua) dengan alasan bahan pembuatan relatif mudah didapat dan memiliki harga yang murah.

Perubahan materi pembentuk Gordang Sambilan tidak hanya bagian dari proses adaptasi terhadap wilayah geografis tempat tinggal masyarakatnya melainkan juga turut merubah pemahaman mengenai simbolik ekologis yang ditunjukkan oleh materi pembentuknya. 
Proses pemahaman ekologis melalui materi pembentuk mengajarkan masyarakat akan kearifan lokal yang diselubungi oleh folkore-magis, dan ketika terjadi perubahan tempat tinggal yang turut merubah materi pembentuk maka pengetahuan masyarakat terhadap ekologis materi pembentuk menjadi kurang bahkan hilang sama sekali.

Perubahan wilayah yang turut merubah materi pembentuk juga menggeser pemahaman masyarakat yang berbasis pengetahuan terhadap alam menjadi pemahaman akan nilai ekonomis semata yang meninggalkan folklore-magis yang melekat pada materi pembentuk Gordang Sambilan.

\section{Repertoir Ekologis}

Simbol ekologis selain dari materi pembentuk Gordang Sambilan terdapat pada repertoir Gordang Sambilan yang selalu berkaitan dengan alam (tabel 2).

Selain repertoir yang telah disebutkan juga terdapat beberapa repertoir lainnya yang menggambarkan hubungan antara manusia dengan lingkungan sekitar (tumbuhan, hewan, ritus kehidupan), seperti Gondang Sarama Babiat (tarian Harimau) yang merepresentasikan hubungan antara manusia dan Harimau (Babiat) dimana Harimau dalam masyarakat Batak-Mandailing memiliki posisi yang dihormati dengan segala kemampuannya.

Penggambaran repertoir dengan menggunakan imaji ekologi memberi penegasan akan kedekatan masyarakat Batak-Mandailing dengan alam yang melingkupi wilayahnya. Terbentuknya repertoir
Gordang Sambilan didasarkan pada suatu kejadian yang telah terjadi (bahkan perulangan) yang menjadi usaha mendokumentasikan hal tersebut, dengan

Tabel 2

Hubungan Repertoir Gordang Sambilan dan Simbolik Ekologis

\begin{tabular}{|c|c|}
\hline $\begin{array}{l}\text { Repertoir Gordang } \\
\text { Sambilan }\end{array}$ & Simbolik Ekologis \\
\hline $\begin{array}{l}\text { Gondang Sarama } \\
\text { Datu }\end{array}$ & $\begin{array}{l}\text { Posisi Datu sebagai wakil atau } \\
\text { perantara antara manusia } \\
\text { dengan Tuhan yang } \\
\text { menggambarkan hubungan } \\
\text { antara Pencipta dan masyarakat }\end{array}$ \\
\hline $\begin{array}{l}\text { Gondang Paturun } \\
\text { Sibaso }\end{array}$ & $\begin{array}{l}\text { Mengundang roh leluhur untuk } \\
\text { datang dan merestui acara } \\
\text { tersebut yang direpresentasikan } \\
\text { dalam tubuh Datu }\end{array}$ \\
\hline Gondang Pamulihon & $\begin{array}{l}\text { Pemulihan dari kondisi Paturun } \\
\text { Sibaso atau sebagai ucapan } \\
\text { terima kasih kepada roh leluhur } \\
\text { telah datang dan merestui acara } \\
\text { tersebut }\end{array}$ \\
\hline $\begin{array}{l}\text { Gondang Sampuara } \\
\text { Batu Magulang }\end{array}$ & $\begin{array}{l}\text { Bebatuan yang jatuh seperti air } \\
\text { terjun, hal ini direpresentasikan } \\
\text { dalam bentuk bencana longsor }\end{array}$ \\
\hline $\begin{array}{l}\text { Gondang Dabu-dabu } \\
\text { Ambasang }\end{array}$ & $\begin{array}{l}\text { Secara harfiah berarti } \\
\text { bergugurannya buah mangga, } \\
\text { dan secara ekologis diartikan } \\
\text { adanya perubahan situasi, iklim } \\
\text { dari suatu kondisi ke kondisi } \\
\text { lain }\end{array}$ \\
\hline $\begin{array}{l}\text { Gondang Padang } \mathrm{Na} \\
\text { Mosok }\end{array}$ & $\begin{array}{l}\text { Hutan yang sangat hebatnya } \\
\text { terbakar, kondisi } \\
\text { menyimbolkan kondisi } \\
\text { terbakarnya hutan }\end{array}$ \\
\hline Gondang Tua & Sebagai sesuatu yang dihormati \\
\hline Gondang Naipasnai & $\begin{array}{l}\text { Secara harfiah berarti yang } \\
\text { tercepat }\end{array}$ \\
\hline Gondang Udan Potir & $\begin{array}{l}\text { Menggambarkan suasana } \\
\text { derasnya hujan yang turun dan } \\
\text { disertai dengan petir (kilat) } \\
\text { yang menyambar }\end{array}$ \\
\hline
\end{tabular}


tujuan menghindari terjadinya bencana alam maupun sebagai tanda akan terjadinya sesuatu pada kondisi alam.

Simbolik ekologis pada repertoir Gordang Sambilan dapat dibagi menjadi tiga kategori utama, yaitu : ekologis manusia dan pencipta, ekologi manusia dan manusia, serta ekologi manusia dan alam. Ekologi manusia dan pencipta dalam repertoir Gondang Sarama Datu, Gondang Paturun Sibaso, dan Gondang Pamulihon yang secara implisit menceritakan hubungan timbal balik antara manusia dan alam dengan menggunakan pemahaman manusia dan Tuhan. Hal ini merepresentasikan permohonan dan ucapan terima kasih kepada sang Pencipta atas anugerah alam (keuntungan maupun bencana) yang mampu menaungi kehidupan manusia.

Pada repertoir Sampuara Batu Magulang, Dabudabu Ambasang, Padang Na Mosok, dan Udan Potir tampak jelas pemahaman masyarakat akan kejadian ekologis yang dialami. Seperti Sampuara Batu Magulang yang didefinisikan sebagai jatuhnya bebatuan seperti air terjun menggambarkan kondisi alam (bencana) longsor.

\section{Simbolik Bolang}

Selain bentuk simbolik ekologis, Gordang Sambilan memiliki hubungan dengan aspek lain yang menyimbolkan sistem budaya Dalihan Na Tolu dan pemahaman kebudayaan Batak-Mandailing.

Hubungan-hubungan yang tercipta dalam Gordang Sambilan menyimbolkan suatu pengetahuan atas pemahaman kebudayaan BatakMandailing yang terkadang berjalan tanpa disadari, materi Gordang Sambilan yang dibentuk oleh sembilan gendang berukuran besar sudah memiliki simbol dari keterwakilan sembilan kampung di wilayah Batak-Mandailing.

Menariknya, simbolisasi yang terdapat pada Gordang Sambilan tidak serta merta diketahui oleh masyarakat penggunanya dikarenakan simbolisasi dan pemahaman akan budaya Batak-Mandailing telah larut dalam bentuk kehidupan sehari-hari.

Sembilan buah gendang pada Gordang Sambilan dibentuk atas pemahaman bilangan ganjil, yaitu penggunaan bilangan tiga sebagai simbol dari Dalihan Na Tolu yang yang terdapat dalam bentuk keluarga (Ayah-Ibu-Anak), dimana Ayah mewakili suatu susunan kekerabatan tertentu yang tampak pada marga begitu juga dengan pihak Ibu, sedangkan Anak menjadi bentuk baru dari susunan kekerabatan yang akan diciptakannya.

Selain bentuk materi Gordang Sambilan yang memiliki makna simbolis, dalam bentuk penggunaan Gordang Sambilan juga menyimpan makna simbolis yang terkait dengan bolang atau ornamen tradisional Batak-Mandailing, hubungan keduanya menimbulkan adanya hubungan antar simbol sebagai pesan budaya.

Bolang dalam kehidupan sehari-hari masyarakat Batak-Mandailing dikenal dengan istilah jagar-jagar yang memiliki nilai kepatuhan oleh masyarakat terhadap adat istiadat. 
Bolang pada prakteknya tidak terbatas pada simbol kehidupan masyarakat, tetapi juga berlaku dalam Gordang Sambilan. Gordang Sambilan tidak akan pernah bisa untuk dimainkan selama Raja tidak memberikan izin, begitu juga dalam bentuk permainan Gordang Sambilan yang menggambarkan praktek dari raga-raga dan jagarjagar untuk menghasilkan bentuk permainan yang harmonis.

Gordang Sambilan dengan sembilan buah gendang merupakan suatu kesatuan yang utuh seperti yang disimbolkan oleh bona bulu dan setiap pemain Gordang Sambilan menjalankan nilai sipatomu-tomu dengan mengerti bagiannya masingmasing dalam permainan maupun pertunjukan Gordang Sambilan.

Gambar 1

Bolang atau Ornamen Tradisional Batak-Mandailing

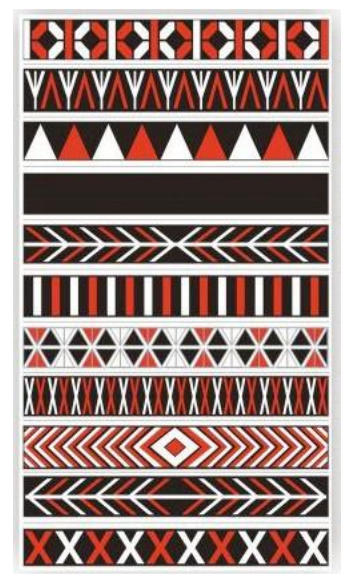

(Dokumentasi : Avena Matondang)

Bolang juga dipergunakan dalam permainan Gordang Sambilan seperti tampak dalam pemakaian kostum panyarama (penari) dan pemain Gordang
Sambilan yang menggunakan baju dengan motif bolang.

Tabel 3 Simbolik Bolang

\begin{tabular}{|c|c|}
\hline Nama Simbol & Keterangan \\
\hline Bintang Na Toras & Pendiri huta atau kampung \\
\hline Rudang & $\begin{array}{l}\text { Atribut kebesaran yang dimiliki } \\
\text { oleh kampung tersebut, meliputi } \\
\text { Gordang Sambilan, bendera, } \\
\text { umbul-umbul, dan lain-lain. }\end{array}$ \\
\hline Pusuk Ni Robung & $\begin{array}{l}\text { Gambaran segitiga yang memiliki } \\
\text { nilai Dalihan Na Tolu dalam } \\
\text { kehidupan }\end{array}$ \\
\hline $\begin{array}{l}\text { Alaman Silangse } \\
\text { Utang }\end{array}$ & $\begin{array}{l}\text { Daerah kekuasaan Raja, setiap } \\
\text { individu yang meminta } \\
\text { perlindungan di daerah kekuasaan } \\
\text { maka wajib dilindungi }\end{array}$ \\
\hline Sancang Duri & $\begin{array}{l}\text { Diartikan sebagai kejadian yang } \\
\text { tidak terduga, apabila ada } \\
\text { pendatang maka wajib ditolong } \\
\text { dan diberi penginapan di Sopo } \\
\text { Godang dan dilindungi oleh } \\
\text { pemimpin atau Namora Natoras }\end{array}$ \\
\hline Bona Bulu & $\begin{array}{l}\text { Suatu sistem pemerintahan Huta } \\
\text { yang terdiri dari Namora Natoras, } \\
\text { Raja, Hulubalang, Datu, Sibaso, } \\
\text { dan lain-lain. }\end{array}$ \\
\hline Aropik & $\begin{array}{l}\text { Setiap upacara adat (ritual) dan } \\
\text { hiburan harus mendapatkan izin } \\
\text { terlebih dahulu dari Raja ataupun } \\
\text { Namora Natoras }\end{array}$ \\
\hline Raga-raga & Keteraturan hidup bersama \\
\hline Bondul Na Opat & $\begin{array}{l}\text { Setiap permasalahan harus } \\
\text { diselesaikan melalui mustawarah } \\
\text { di Sopo Godang dengan } \\
\text { keputusan yang adil }\end{array}$ \\
\hline Sipatomu-tomu & $\begin{array}{l}\text { Hak dan kewajiban bagi Raja dan } \\
\text { Situan Najaji }\end{array}$ \\
\hline Jagar-jagar & $\begin{array}{l}\text { Kepatuhan dari masyarakat } \\
\text { terhadap nilai-nilai adat istiadat }\end{array}$ \\
\hline
\end{tabular}

Bentuk dari sebelas struktur ornamen tradisional Batak-Mandailing menjadi pengetahuan 
pikiran (kognitif) yang tersimpan dan dipraktekkan dalam setiap aspek kehidupan.

\section{Simpulan}

Hubungan antara Gordang Sambilan (materi seni) dengan repertoir (judul komposisi) menggambarkan suatu pola hubungan yang berkaitan dengan lingkungan alam (ekologi), sehingga penggambaran terhadap Gordang Sambilan tidak lepas dari pengaruh kondisi lingkungan alam setempat. Faktorfaktor ritual dan hiburan yang muncul dari penggunaan Gordang Sambilan secara langsung membawa perubahan ekologi materi pembentuk Gordang Sambilan namun masih mempertahankan kearifan ekologis yang tersimpan dari beragam repertoir yang masih dimainkan hingga saat ini.

Korelasi antara ekologi dan Gordang Sambilan mengukuhkan peran lingkungan alam dalam pembentukan Gordang Sambilan, baik secara materi maupun penggunaan (repertoir). Kearifan ekologis ini juga memberi nilai pada hubungan antara manusia dengan ketersediaan alam yang berlangsung seimbang.

\section{Daftar Acuan}

Diapari, L.S. gelar Patuan Naga Humala Parlindungan. 1990. Adat Istiadat Perkawinan Dalam Masyarakat Tapanuli Selatan.

Emerson, Fretz, dan Linda L Shaw. 1995. Writing Ethnography Fieldnotes. Chicago and London: The University of Chicago Press.
Goodenough, Ward E. 1970. Description and Comparison in Cultural Anthropology. Cambridge University Press.

Hodges, William Robert Jr. 2009. Ganti Andung, Gabe Ende (Replacing Laments, Becoming Hymns): The Changing Voice of Grief in the Prefuneral Wakes of Protestant Toba Batak (North Sumatra, Indonesia). Santa Barbara: Disertasi Ph.D University of California (tidak diterbitkan).

Jackson, Bruce. 1987. Field Work. Urbana and Chicago. University of Illinois Press.

Kozok, Uli. 2009. Surat Batak; Sejarah Perkembangan Tulisan Batak. Jakarta: Ècole française d'Extrème-Orient - $\quad \mathrm{KPG}$ (Kepustakaan Populer Gramedia).

Lubis, Z Pangaduan dan Zukifli Lubis. 1998. Sipirok Na Soli, Bianglala Kebudayaan Masyarakat Sipirok. Medan: USU Press.

Maanen, J. Van. 1996. Ethnography. Dalam A. Kuper and J. Kuper (Eds) The Social Science Encyclopedia, 2nd ed., pages 263-265. London: Routledge.

Matondang, Ibnu Avena. 2008. Gordang Sambilan; Video Etnografi tentang Penggunaannya ditengah- tengah Masyarakat Mandailing di Kota Medan. (32 menit 13 detik). Medan: Skripsi Sarjana S1 Departemen Antropologi Fakultas Ilmu Sosial dan Politik - Universitas Sumatera Utara (tidak diterbitkan).

Merriam, Allan P. 1964. The Anthropology of Music. Evanston - Illinois: Northwestern University Press.

Nas, Peter J.M. 1998. Social and Cultural Development of Human Resources - Social Ecology in Urban Setting. (OEncyclopedia of Life Support Systems (EOLSS).

Nasution, Pandapotan. 2005. Adat Budaya Mandailing dalam Tantangan Zaman. Medan: Forkala Provinsi Sumatera Utara. Purba, Mauly. 2004. Mengenal Tradisi Gondang Dan Tortor Pada Masyarakat Batak 
Toba. Dalam Ben M. Pasaribu (Ed) : Pluralitas Musik Etnik : Batak-Toba, Mandailing, Melayu, Pakpak-Dairi, Angkola, Karo dan Simalungun. Medan: Pusat Dokumentasi Dan Pengkajian Kebudayaan Batak Universitas HKBP Nomensen.

Sibeth, Achim. 1991. Living With The Ancestor; The Batak; Peoples of the Island of Sumatra. London. Thames and Hudson.

Siregar, Ahmad Samin. 1977. Kamus Bahasa Angkola/Mandailing. Jakarta: Pusat Pembinaan dan Pengembangan Bahasa Departemen Pendidikan dan Kebudayaan. 